\title{
Photovoltaics for Residential Applications
}

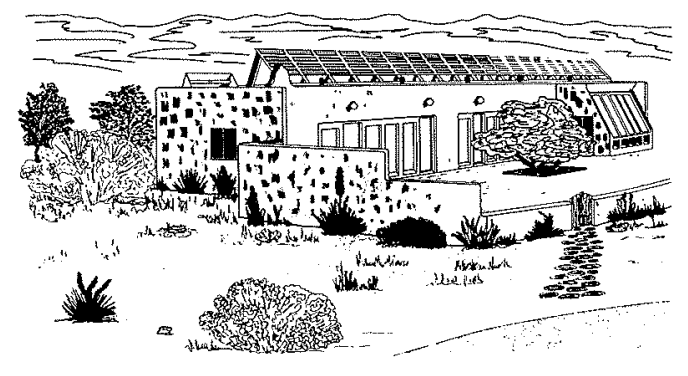

SERI/SP-281-2190

UC Category: 58B, 58D, 63

$\checkmark \quad$ DE84004434

Published February 1984

The information presented on the pages that follow has been prepared as an introduction for architects and technologists involved in residential photovoltaics use. The material is intended to inform the reader about the parts of a residential PV system and considerations relevant to PV's use in homes that are also tied to utility lines. It supplements material in Basic Photovoltaic Principles and Methods, providing a framework for understanding basic design considerations for residential PV systems; it should not be used for design purposes. The reader in need of design information is referred to the Design Handbook for Photovoltaic Systems.

Additional information may be found in the Sandia Laboratory series of 13 topical reports to be published during 1984. The series will provide extensive coverage of a broad range of information relating to residential PV system designs including system feasibility, utility-based value and system impacts, institutional requirements, system performance/economic modeling, software, tradeoffs and options, array subsystem design, power controls, power control/array interface, safety start-up and checkout, energy storage and direct current (dc) loads, and PV/thermal flat-plate collectors.'

'Specific questions maybe addressed to personnel at any of three regional DOE-sponsored outdoor labs at Carlisle, MA, (617) 863-5770; Las Cruces, NM, (505) 646-4240; and Cape Canaveral, FL, (305) 783-0300. 


\section{Acknowledgements}

This document was prepared under the auspices of the Photovoltaic Energy Technology Division, Office of Renewable Technology, U.S. Department of Energy. Specific direction was provided by Vince Rice of the DOE Photovoltaic Energy Technology Division and Joseph Holmes, manager of the DOE Solar Information Program. The document was produced by the Technical Information Branch of the Solar Energy Research Institute. Principal participants in that production were: Paul Hersch, Noni Strawn, Dick Piekarski and Gary Cook. The document was reviewed by Jack Stone and David Waddington, both of the SERI Solar Electric Conversion Division. 


\section{Contents}

\section{Chapter 1. Introduction}

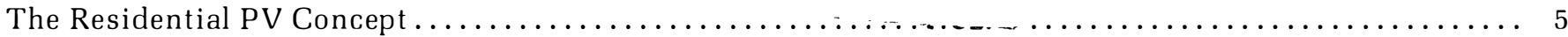

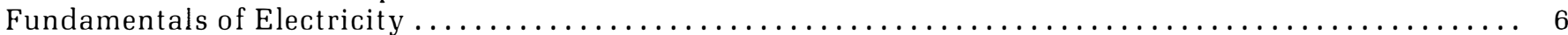

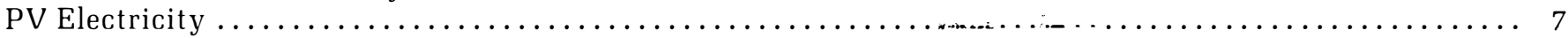

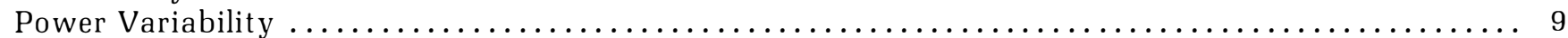

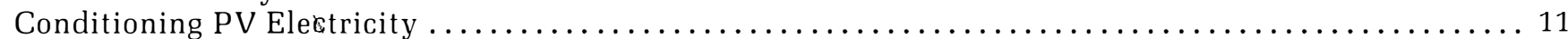

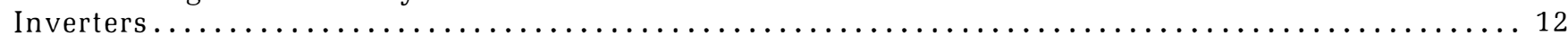

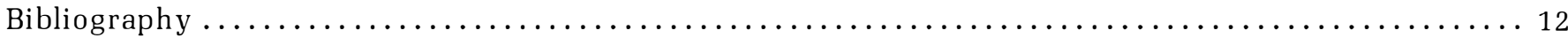

\section{Chapter 2. Incorporating Residential PV}

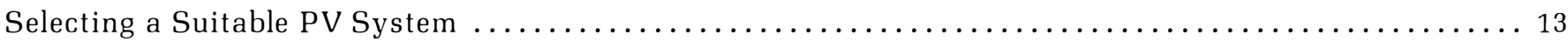

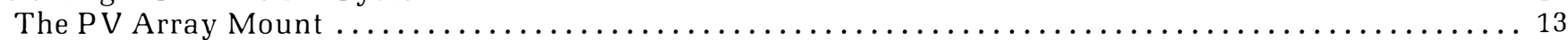

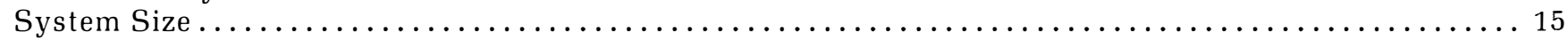

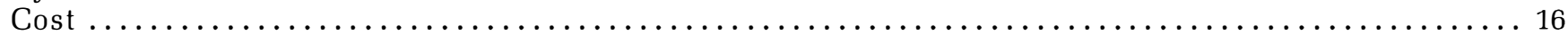

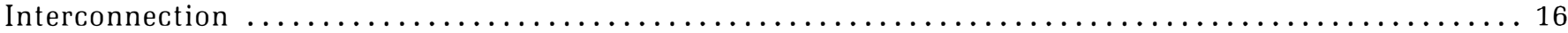

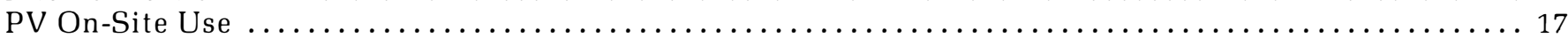

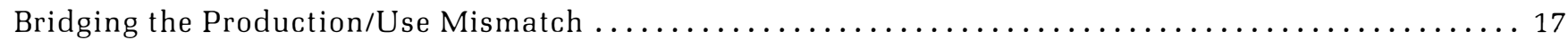

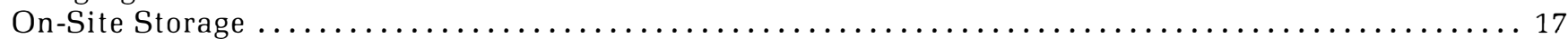

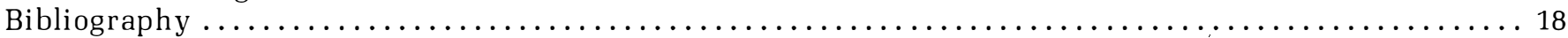

\section{Chapter 3. Factors Influencing Implementation}

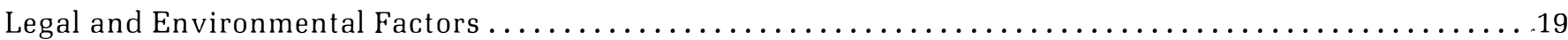

Solar Access ............................................................ 19

Building Codes ............................................................ 20

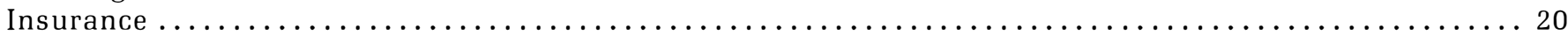

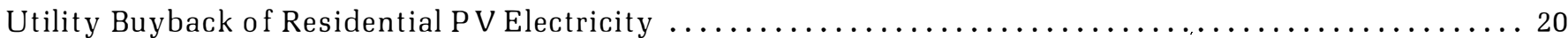

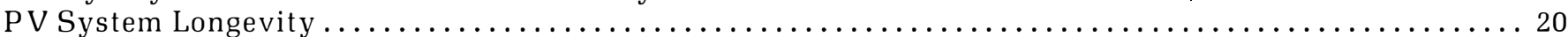

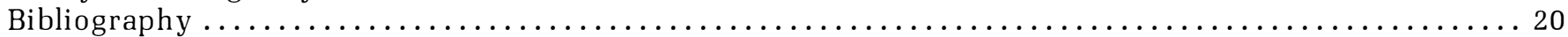

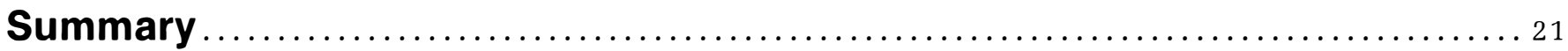

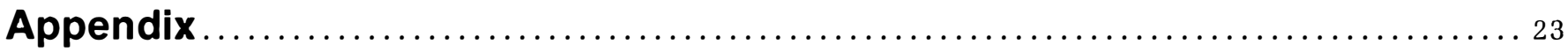





\section{Chapter 1 \\ Introduction}

Some people are skeptical about residential photovoltaics (PVs) being used anywhere except in such sun-basked areas as the American Southwest. The fact is that there is enough sunshine throughout most of the United States to support the use of residential PV systems (Figure 1). The problem is whether suitable PV systems can be designed to meet the residential electrical requirements in different regions, considering the cost of $\mathrm{PV}$, the amount of sunlight available, and regional electricity prices. Additionally, how well the PV system at any location succeeds depends on sociopolitical and legal influences, including the acceptance of the concept by the local electrical utility.

\section{The Residential PV Concept}

In 1963, photovoltaics were incorporated (along with a conventional system) into the design of a house in Newark, DE. During, the decades following the Newark experiment, scientists and engineers have developed improved PV cells and prototype systems for standard residential PV designs. Their objective has been to strengthen PV as a renewable energy option in the large residential markets of the United States.

There are two ways to connect the PV home with utility power lines. The hookup can be one-directional,

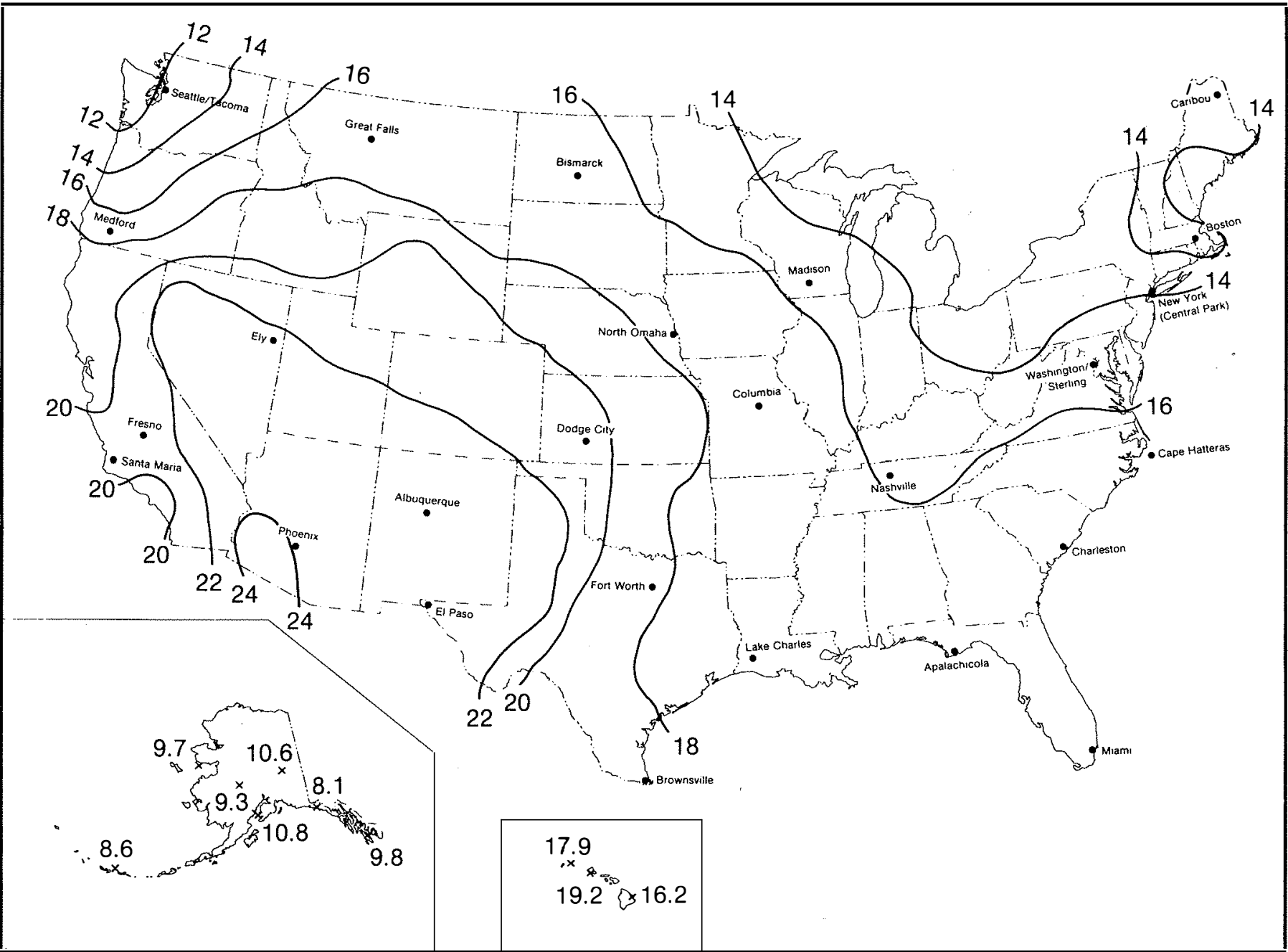

Figure 1. Average daily global solar radiation on a south facing surface, tilt $=$ lattitude $\left(\mathrm{MJ} / \mathrm{m}^{2}\right)$. Sufficient sunlight floods most of the United States, making residential PV practical on a year-round basis in all but about $10 \%$ of the country. 
from utility to homę, providing power as needed to the home; or the hookup can be one that allows PV power to flow from the house to utility lines, and utility power to flow to the house. This monograph explains the technical principles and considerations relating to the latter, two-way, exchange. Figure 2 shows a grid-interconnected system for which there are two schemes. Electricity is bought from the utility to supplement the energy supplied by the PV source and, alternatively, the PV system's excess electricity is fed into the power lines for buyback by the utility. The homeowner may also elect to sell all PV-generated electricity to the utility and then buy all energy needs from the utility. In either case, the utility grid, by absorbing PV-generated electricity at one point in time and supplying electricity at another time, is acting as a storage system.

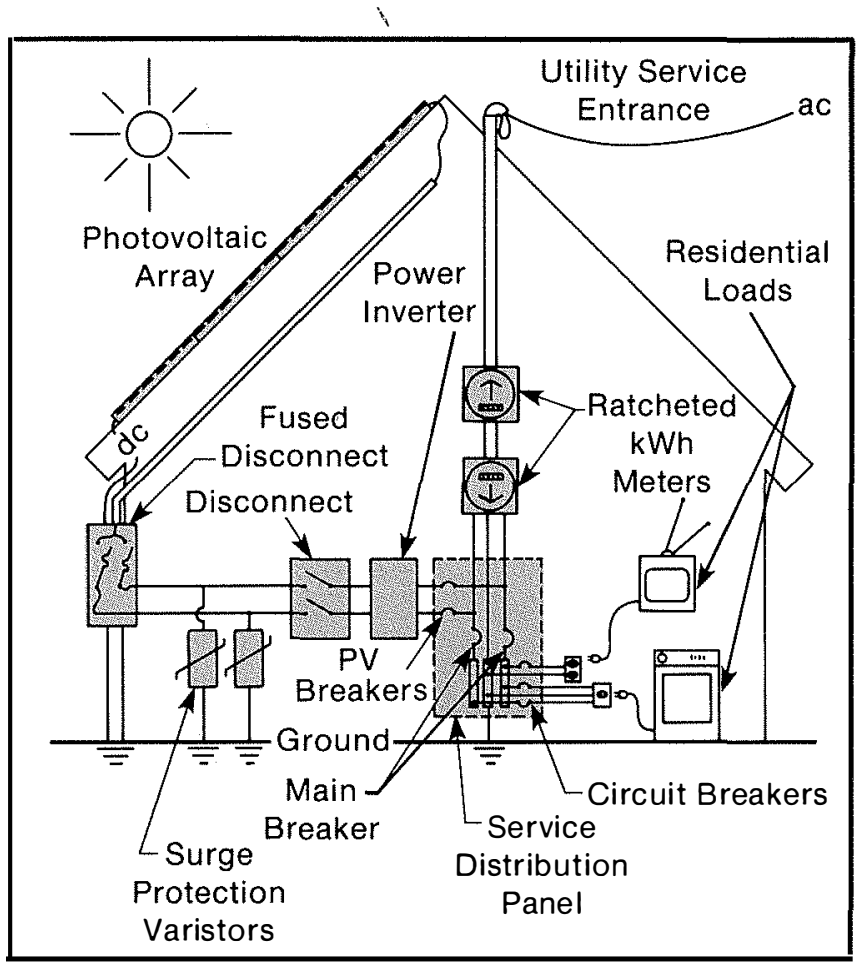

Figure 2. A generic, utility-tied residential PV system composed of the PV array, a power conditioner and associate equipment, and a two-way tie to the utility's lines.

The essential components of an interconnected system are the PV panels, usually on the roof, which generate the electricity; a power-conditioning unit for processing the electricity so that it is utilitycompatible; and equipment to feed and measure the power exchange between the house and the utility grid.

\section{Fundamentals of Electricity}

To understand a PV/grid-connected system, factors particular to feeding PV-produced power into a utility grid are noteworthy. In contrast to the dc nature of PV electricity, most U.S. utilities generate alter- nating current $(\mathrm{ac})$. Certain factors in ac electricity have no dc counterparts; they are ac's reactive elements. There is inductive reactance which is produced by a coiled wire (inductor) in the ac circuit. This inductor reacts to an ac source by inducing an opposing voltage that is directly proportional to the size of inductance and frequency of the circuit voltage. The induced reactance is felt as a circuit load and diminishes usable electric power. There is also capacitive reactance, typically produced by two separated conductors in the ac circuit. The device designed to exploit this effect is known as a capacitor. Alternating current can conduct through a capacitor, however, a charge buildup for each cycle of ac opposes the circuit voltage. This causes a loss in available power that is inversely proportional to the size of the capacitance and to the frequency of the circuit voltage.

While imposing reactive loads, inductances and capacitances shift the peaking relationships of the ac current and voltage waves (Figure 3). Inductors retard the current wave while capacitors advance it with respect to the voltage. The lead or lag between current and voltage can be expressed in terms of a power factor (PF), which ranges between 0 and 1 . The larger

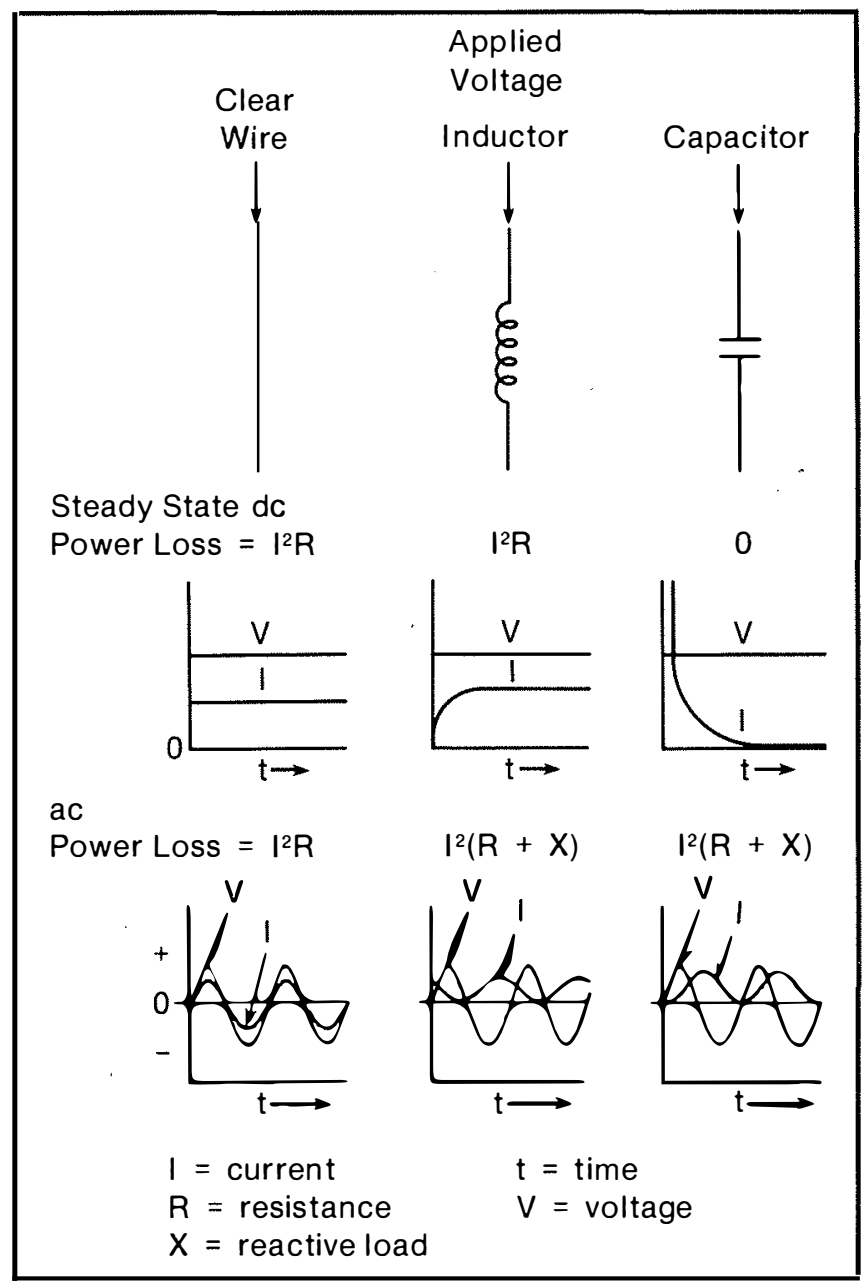

Figure 3. In ac circuits, the current curve will lead the voltage curve for inductive circuits and will lag the voltage for capactive circuits. 
the reactive power losses, the greater the lead or lag, and the smaller the PF. Where there is no power loss, the PF is 1. (Standard residential loads typcially operate with a PF of 0.85 lagging to unity.) Power factor losses created by the PV system's powerconditioning equipment can be injected into the utility grid, a consideration when choosing equipment. A utility may refuse to purchase electricity from homes equipped with poorly matched conditioners.

Harmonics ${ }^{2}$ must also be considered in de to ac conversion. Converting dc to ac can generate oddmultiple frequencies at power levels that are less than that of the main wave $(60 \mathrm{~Hz})$, thereby reducing overall power.

\section{PV Electricity}

The capacity to produce a photovoltaic effect (conversion of sunlight to electricity) exists only for certain materials. Of particular interest for power generation are semiconductor materials. These are insulators at absolute zero, but because of thermal molecular agitation and inherent or intentionally added impurities, they have a room-temperature resistance between that of a conductor and an insulator. With suitable treatment, semiconductors can be made into photovoltaic devices. The semiconductor material and its method of manufacture define its performance and economics in PV applications.

One of the first materials considered for residential PV cells was silicon. There are several forms of silicon: single-crystal, polycrystalline, and amorphous (noncrystalline structure). Single-crystal silicon was the first widely used material for residentially-sized power applications. Polycrystalline material was made suitable for commercial PV installations sometime after single-crystal. Amorphous silicon is still undergoing research to improve PV performance and its use in residential design has been minor in the United States. ${ }^{3}$

Single-crystal silicon has a substantial performance edge over polycrystalline and amorphous silicon cells, but the latter two are considerably less costly to fabricate. Researchers continue to explore PV systems based on all three silicon materials, but with different emphases. For single-crystal cells, the stress is on reducing production cost; for polycrystalline and amorphous silicon cells, the accent is on enhancing efficiencies.

The basic unit of the PV system is the PV cell, a wafer of photovoltaic material (generally silicon) with positive and negative leads (Figure 4). Cells for residential use are commonly less than $10 \mathrm{~cm}$ diameter or

\footnotetext{
2Harmonic: any frequency that is generated as a multiple of the primarysignal (e.g., $120 \mathrm{~Hz}, 180 \mathrm{~Hz}, 240 \mathrm{~Hz}$, etc., where the main signal propagates at $60 \mathrm{~Hz}$ ).

${ }^{3}$ The Japanese PV industry, including Sanyo, has installed several experimental residential PV units using amorphous silicon.
}

$10 \mathrm{~cm}$ square, producing about $1 \mathrm{~W}$ at $0.5 \mathrm{~V}$ where the solar intensity is $1000 \mathrm{~W} / \mathrm{m}^{2}$ and the PV cell temperature is $25^{\circ} \mathrm{C}$.

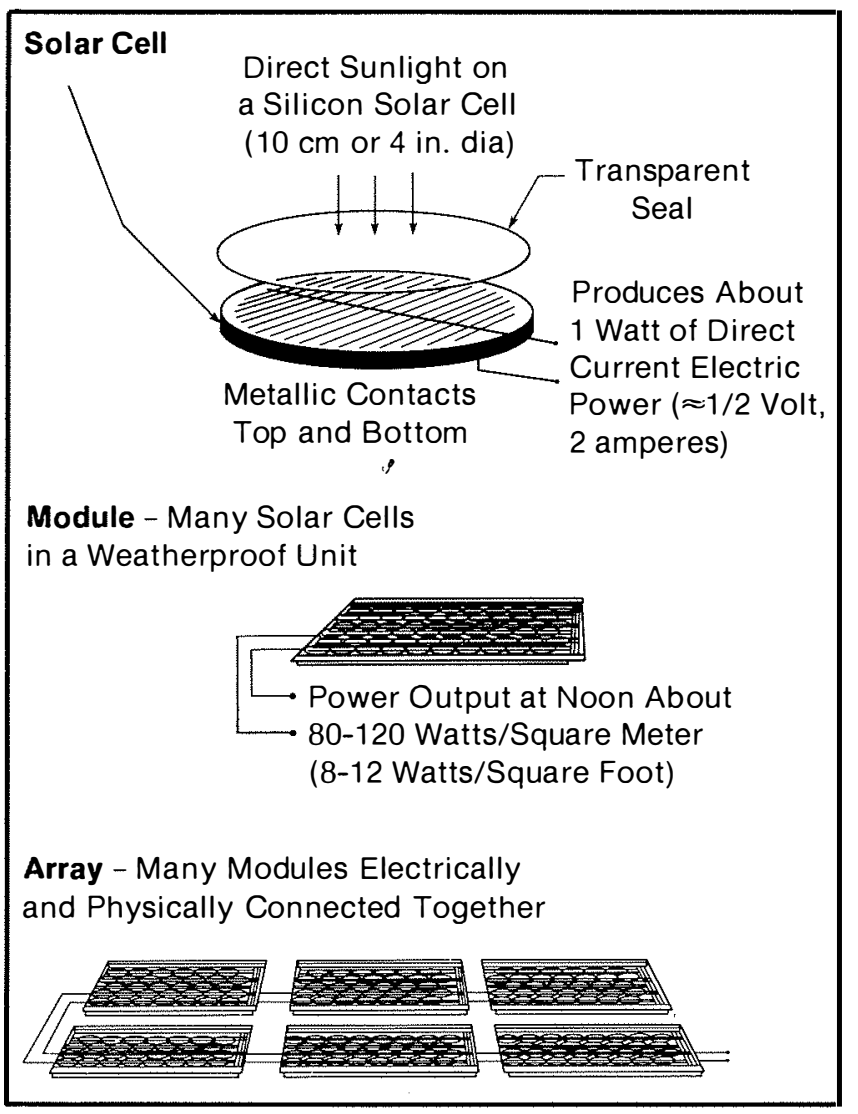

Figure 4. The basic hierarchy of the PV generator is the solar cell; the module, group of cells connected in various series or parallel arrangements); and the array (group of modules connected in a suitable series-parallel configuration).

PV cells are connected to form modules (Figure 4) by wiring either serially (positive to negative contaets) to increase electric voltage, or in parallel (all positives joined, all negatives joined) to increase electrical current. ${ }^{+}$

Although commercially-made PV cells can convert sunlight to electricity at almost $15 \%$ efficiency, module efficiencies may only reach $5 \%-10 \%$ (Table 1 ). Factors responsible for diminished efficiency include electrical connection losses and losses due to inactive module areas (i.e., the area between individual cells).

There are no standard residential modules. Even module manufacturers using the same PV cells are not likely to turn out products with the same cell arrangements. Module size will depend on a given designer's idea of a proper compromise between power' output and other factors, such as handling convenience. A typical module, however, might produce $15 \mathrm{~V}$ at $2 \mathrm{~A}$ under temperature and sunlight conditions of $25^{\circ} \mathrm{C}$ and $1 \mathrm{~kW} / \mathrm{m}^{2}$. Many manufactur-

\footnotetext{
${ }^{4}$ It is also possible to increase current by intensifying the light incident on the PV cell(s) by optically concentrating the sun. Few, if any, residential PV systems deploy such concentrator units.
} 
Table 1. PV Data for Residential Experimental Test Sites

\begin{tabular}{|c|c|c|c|c|c|c|c|c|c|c|c|c|}
\hline \multirow{2}{*}{$\begin{array}{c}\text { Test } \\
\text { Location }\end{array}$} & \multicolumn{2}{|c|}{ Manufacturer } & \multirow{2}{*}{$\begin{array}{l}\text { Cells in Module } \\
\text { Series } \times 2\end{array}$} & \multirow{2}{*}{$\begin{array}{l}\text { Module Size } \\
(\mathrm{cm} \times \mathrm{cm})\end{array}$} & \multirow{2}{*}{$\begin{array}{l}\text { Cell } \\
\text { Pack } \\
(\%)\end{array}$} & \multirow{2}{*}{$\begin{array}{c}\text { Cell } \\
\text { Efficiency } \\
(\%)\end{array}$} & \multirow{2}{*}{$\begin{array}{l}\text { Manufacturer } \\
\text { Modules in Array } \\
\text { Series } \times \text { Parallel }\end{array}$} & \multirow{2}{*}{$\begin{array}{c}\text { Array } \\
\text { Dimensions } \\
(\mathrm{m})\end{array}$} & \multicolumn{2}{|c|}{ Mount } & \multirow{2}{*}{$\begin{array}{l}\text { Cell } \\
\text { Power } \\
(\mathrm{kW})^{\dagger}\end{array}$} & \multirow{2}{*}{$\begin{array}{c}\text { Array } \\
\text { Efficiency } \\
(\%)\end{array}$} \\
\hline & Array & Module & & & & & & & Type $^{*}$ & Tilt & & \\
\hline \multirow{6}{*}{ Carlisle, MA } & Solarex & Solarex & $36 \times 2$ & $38 \times 120$ & 93 & & $13 \times 6$ & $5.3 \times 13.4$ & $S$ & $40^{\circ}$ & & 7 \\
\hline & TriSolar & $\begin{array}{l}\text { Applied } \\
\text { Solar } \\
\text { Energy }\end{array}$ & $23 \times 11$ & $78 \times 162$ & 82 & 13 & $18 \times 2$ & $3.3 \times 14.7$ & 1 & $45^{\circ}$ & 4.8 & 11 \\
\hline & GE & GE & $19 \times 1$ & $\left(1995 \mathrm{~cm}^{2}\right)^{\ddagger}$ & 70 & 12 & $25 \times 15$ & $6.0 \times 12.3$ & $\mathrm{D}$ & $34^{\circ}$ & 6.7 & 9 \\
\hline & Westinghouse & Arco & $35 \times 1$ & $30 \times 120$ & 80 & 13 & $13 \times 12$ & $5.3 \times 14.5$ & $S$ & $45^{\circ}$ & 5.2 & 7 \\
\hline & MIT & Solarex & $36 \times 2$ & $63 \times 120$ & 84 & 10 & $14 \times 8$ & $6.4 \times 14.7$ & S & $45^{\circ}$ & 7.0 & 7 \\
\hline & Solar Design & Solarex & $36 \times 2$ & $63 \times 120$ & 84 & 10 & $14 \times 9$ & $4.4 \times 22$ & 1 & $45^{\circ}$ & 7.8 & 8 \\
\hline \multirow[t]{8}{*}{ Las Cruces, NM } & TriSolar & $\begin{array}{l}\text { Applied } \\
\text { Solar } \\
\text { Energy }\end{array}$ & $36 \times 2$ & & & & $22 \times 2$ & $3.3 \times 17.7$ & 1 & $30^{\circ}$ & 5.2 & 9 \\
\hline & Solarex§ & Solarex & $36 \times 2$ & $66 \times 127$ & & & $13 \times 6$ & $5.2 \times 13.5$ & S & $26^{\circ}$ & 5.1 & 7 \\
\hline & BDM & Motorola & $33 \times 1$ & $36 \times 120$ & & & $13 \times 9$ & $\begin{array}{l}3.8 \times 9.4+ \\
3.8 \times 4.7\end{array}$ & $S$ & $35^{\circ}$ & 4.4 & 8 \\
\hline & TEA & Motorola & $33 \times 1$ & $36 \times 120$ & & & $14 \times 8$ & $2.9 \times 17.1$ & $\mathrm{R}$ & $26^{\circ}$ & 4.2 & 8.5 \\
\hline & $\mathrm{GE}^{4}$ & GE & $19 \times 1$ & $53 \times 48$ & & & $25 \times 15$ & $6.1 x=12.5$ & $D$ & $27^{\circ}$ & 6.7 & 9 \\
\hline & Arco & Arco & $20 \times 3$ & $60 \times 120$ & & & $26 \times 5$ & $5.6 \times 17.7$ & $D$ & $25^{\circ}$ & 7.4 & 8 \\
\hline & Westinghouse $^{4}$ & Arco & $35 \times 1$ & $31 \times 120$ & & & $13 \times 12$ & $5.3 \times 14.2$ & 1 & $30^{\circ}$ & 5.5 & 7 \\
\hline & ARTU & Arco & $35 \times 1$ & $35 \times 120$ & & & $12 \times 12$ & $7.4 \times 9.5$ & $S$ & $45^{\circ}$ & 4.9 & 8 \\
\hline
\end{tabular}

${ }^{*} \mathrm{~S}=$ standoff; $\mathrm{I}=$ integral; $\mathrm{D}=$ direct; $\mathrm{R}=$ rack.

${ }^{\dagger}$ Corrected for conditions at $25^{\circ} \mathrm{C}, 1 \mathrm{~kW} / \mathrm{m}^{2}$ insolation.

$\ddagger$ Hexagonal cells in a hexagonal module.

$\S$ Presumably the same as for units at Carlisle. 
ers rate the performance of their modules at an ambient temperature of $20^{\circ} \mathrm{C}$ for an irradiance of $80 \mathrm{~W} / \mathrm{m}^{2}$ with a $1 \mathrm{~m} / \mathrm{s}$ wind helping to cool the unit and maximize voltage output.

Module circuitry often contains blocking or bypass circuits to minimize losses or forestall catastrophic failures of entire strings of cells (series-joined arrangement), entire modules, or even an entire array (Figure 5). A blocking device (diode) is placed within

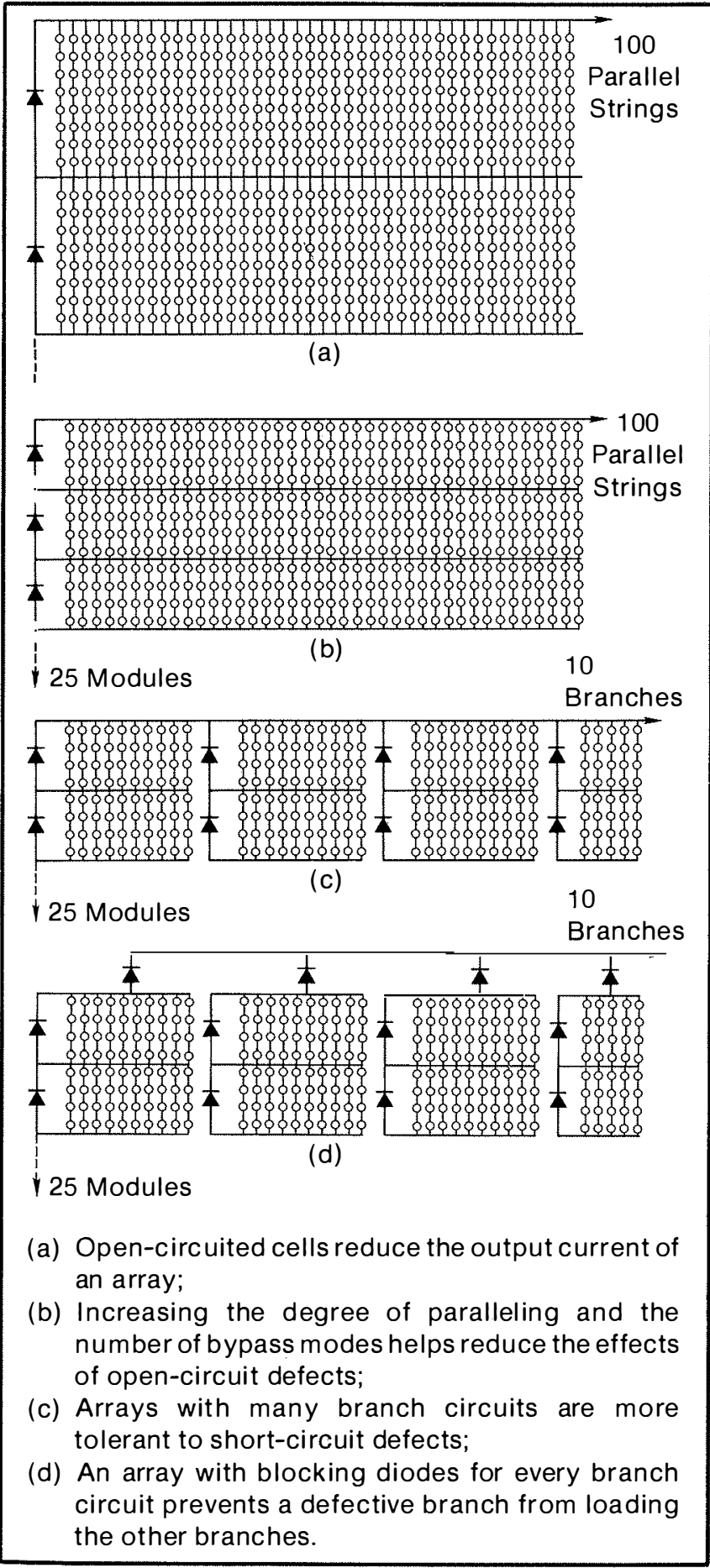

Figure 5. Alternative methods of string wiring modules into arrays show how to place blocking and bypass diodes to avoid degradation or failure of large sections in the event of a single cell's power loss. an assemblage of cells to protect sections of the assembly from reverse current (a possible situation during partial shading of an array) or failure of a module section. Diodes can also be used to bypass failed PV cells in order to maintain current at a level as close to maximum as possible.

Although the ac electricity fed from the residence to the utility is conditioned to be equivalent to that supplied by the utility, there is no standard for the do electric output from PV residential arrays to the conditioners. Some arrays produce about $200 \mathrm{Vdc}$; some residential arrays produce as little as $36 \mathrm{Vdc}$, which, after conversion to ac, is boosted to a utilitycompatible level. A high dc voltage level has both advantages and drawbacks; it reduces conversion losses and voltage-boosting equipment costs, but results in the need for increased safety precautions on the roof and causes arrays to age more rapidly with respect to power-producing capability.

Power Variability. The voltage and current from a PV source will change with temperature (Table 2), lighting, and other conditions (Figures 6 and 7). Sunlight intensity directly affects the current output; other factors, including temperature, affect operating voltage. Rising temperatures degrade performance.

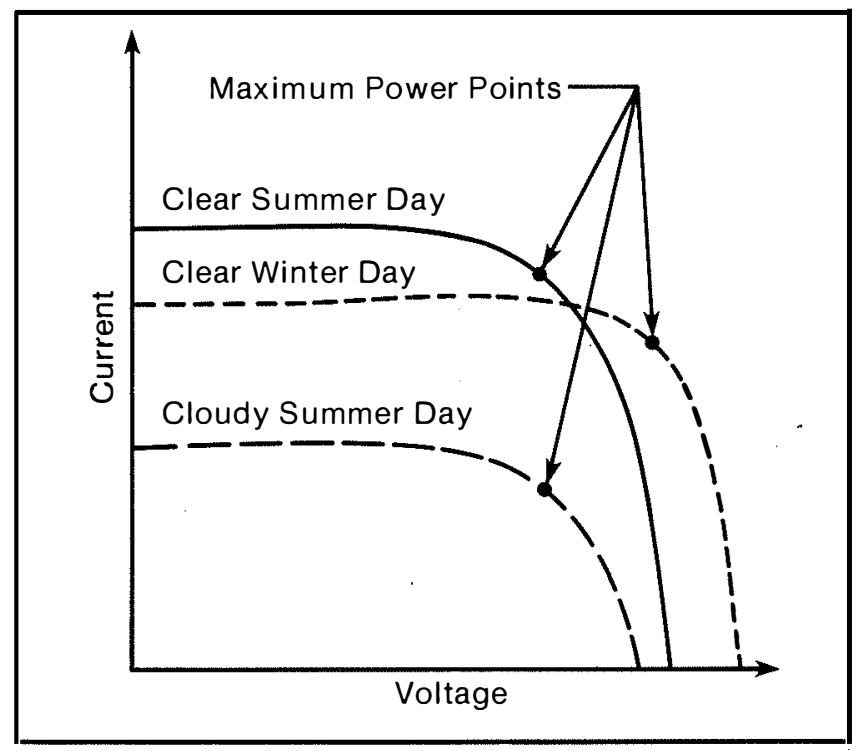

Figure 6. Array performance varies with seasons.

Interestingly, the temperature attained by the module depends on its design (Figure 8) and installation as well as ambient conditions.

The current and voltage from a PV array varies with applied electric load. There is one current/voltage value for which output power from the array is a maximum (Figure 6); this is the most desirable operating level. It is possible to devise control circuitry that tracks for the greatest possible power operation to maximize captured energy; high power efficiency may also be attained by keeping the PV array output voltage constant. 
Table 2. PV Data for Residential Experimental Test Sites

\begin{tabular}{|c|c|c|c|c|c|c|c|c|c|c|c|c|c|c|}
\hline \multirow{3}{*}{$\begin{array}{l}\text { Test } \\
\text { Site }\end{array}$} & \multirow{2}{*}{\multicolumn{2}{|c|}{ Manufacturer }} & \multirow[b]{3}{*}{ Configuration } & \multirow{3}{*}{$\begin{array}{l}\text { Module } \\
\text { Area } \\
\left(\mathrm{cm}^{2}\right)\end{array}$} & \multicolumn{3}{|c|}{ Manufacturer's Data for Module } & \multirow{3}{*}{$\begin{array}{l}\text { Module By- } \\
\text { Pass Diodes }\end{array}$} & \multirow{3}{*}{$\begin{array}{l}\text { Array } \\
\text { Area } \\
\left(\mathrm{m}^{2}\right)\end{array}$} & \multirow{2}{*}{\multicolumn{2}{|c|}{ Array Diodes }} & \multirow{3}{*}{$\begin{array}{c}\text { Array } \\
\text { Power } \\
\left(\mathrm{kW} @{ }^{\circ} \mathrm{C}\right) \\
\end{array}$} & \multicolumn{2}{|c|}{ Efficiencies } \\
\hline & & & & & \multirow{2}{*}{$\begin{array}{l}\text { Open Circuit } \\
\text { Voltage } \\
\text { (V) }\end{array}$} & \multirow{2}{*}{$\begin{array}{l}\text { Closed Circuit } \\
\text { Current } \\
\text { (A) }\end{array}$} & \multirow{2}{*}{$\begin{array}{c}\text { Maximum } \\
\text { Power } \\
\left(\mathrm{W} @{ }^{\circ} \mathrm{C}\right) \\
\end{array}$} & & & & & & & \\
\hline & Array & Module & & & & & & & & Block & Bypass & & $(\%)$ & $(\%)$ \\
\hline \multirow[t]{6}{*}{ Carlisle, MA } & Solarex & Solarex & $\begin{array}{l}\text { Standard } \\
\text { Frame }\end{array}$ & 0.755 & 19.5 & 4.4 & $65 @ 28$ & 6 & -73.0 & 6 & 0 & $5.2 @ 25$ & 7.0 & \\
\hline & TriSolar & $\begin{array}{l}\text { Applied } \\
\text { Solar } \\
\text { Energy }\end{array}$ & Unframed & 1.265 & 13.3 & 13.0 & $132 @ 30$ & 0 & 45.6 & 0 & 18 & $4.8 @ 25$ & 8.0 & 89 \\
\hline & $\mathrm{GE}$ & GE & $\begin{array}{l}\text { Hex }^{1} \\
\text { Shingle }\end{array}$ & 0.196 & 9.3 & 2.4 & $15.4 @ 64$ & 0 & 75.0 & 0 & 0 & $6.7 @ 25$ & 9.0 & $80-85$ \\
\hline & Westinghouse & Arco & $\begin{array}{l}\text { Custom } \\
\text { Frame }\end{array}$ & 0.34 & 18.9 & 2.5 & $34.7 @ 45$ & 0 & 78.0 & 0 & 12 & $5.2 @ 25$ & 7.0 & \\
\hline & MIT & Solarex & $\begin{array}{l}\text { Standard } \\
\text { Frame }\end{array}$ & 0.75 & 17.6 & 48.0 & $58 @ 46$ & 36 & 95.0 & 8 & 0 & $7.0 @ 25$ & 7.0 & 85 \\
\hline & Solar Design & Solarex & $\begin{array}{l}\text { Standard } \\
\text { Frame }\end{array}$ & 0.75 & 17.6 & 48.0 & $58 @ 46$ & 36 & 100.0 & 13 & 0 & $7.4 @ 50$ & 7.0 & 91 \\
\hline \multirow[t]{8}{*}{ Las Cruces, NM } & Solarex & Solarex & Unframed & 0.84 & 17.2 & 5.1 & $56.2 @ 50$ & 3 & 70.2 & 10 & 0 & $4.5 @ 50$ & 6.0 & 85 \\
\hline & TriSolar & $\begin{array}{l}\text { Applied } \\
\text { Solar } \\
\text { Energy }\end{array}$ & Unframed & 1.26 & 9.2 & 13.9 & $105 @ 50$ & 0 & 58.0 & 0 & 44 & $4.9 @ 44$ & 8.5 & 94 \\
\hline & $\mathrm{GE}$ & GE & $\begin{array}{l}\text { Hex } \\
\text { Shingle }\end{array}$ & 0.20 & 9.3 & 2.3 & 15 @ 68 & 0 & 76.2 & 0 & 0 & $5.7 @ 58$ & 7.5 & 84 \\
\hline & Westinghouse & Arco & Unframed & 0.37 & 19.5 & 2.5 & $34 @ 47$ & 0 & 75.2 & 2 & 13 & $4.6 @ 50$ & 6.0 & 84 \\
\hline & Arco & Arco & $\begin{array}{l}\text { Batten/ } \\
\text { Seam }\end{array}$ & 0.72 & 10.1 & 7.1 & $51.8 @ 65$ & 1 & 91.6 & $=5$ & 0 & $6.8 @ 54$ & 7.5 & 90 \\
\hline & ARTU & Arco & $\begin{array}{l}\text { Metal } \\
\text { Frame }\end{array}$ & 0.42 & 19.5 & 2.6 & $34 @ 47$ & 1 & 55.2 & 12 & 0 & $4.5 @ 51$ & 8.0 & 88 \\
\hline & BDM & Motorola & $\begin{array}{l}\text { Metal } \\
\text { Frame }\end{array}$ & 0.43 & 17.9 & 2.6 & $33.3 @ 50$ & 3 & 54.0 & 9 & 0 & $3.8 @ 54$ & 8.0 & $80-85$ \\
\hline & TEA & Motorola & $\begin{array}{l}\text { Metal } \\
\text { Frame }\end{array}$ & 0.43 & 17.9 & 2.6 & $33.3 @ 50$ & 0 & 49.4 & 16 & 112 & $3.8 @ 48$ & 8.0 & $80-85$ \\
\hline
\end{tabular}

\footnotetext{
$10.53 \mathrm{~m}$ on diagonal, $0.49 \mathrm{~m}$ across flat.
} 


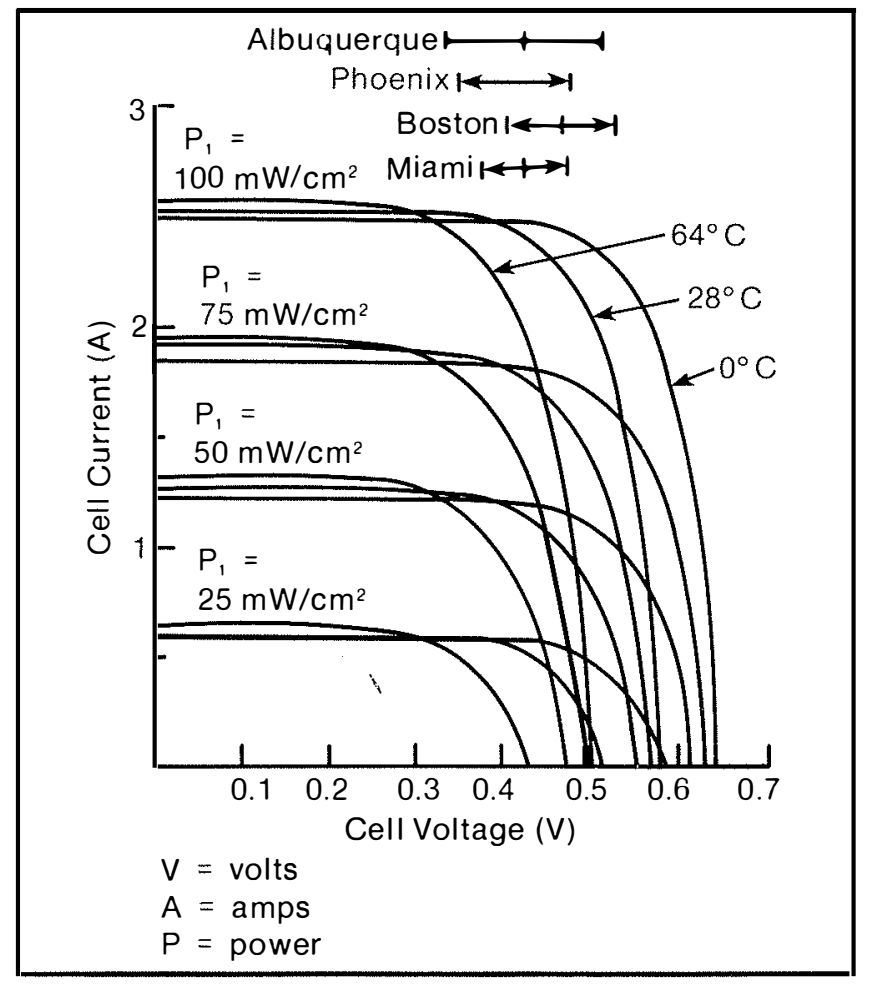

Figure 7. Photovoltaic module performance varies with location. In addition to power performance shown, consideration should be given to total hours of sunshine during which energy can be produced.

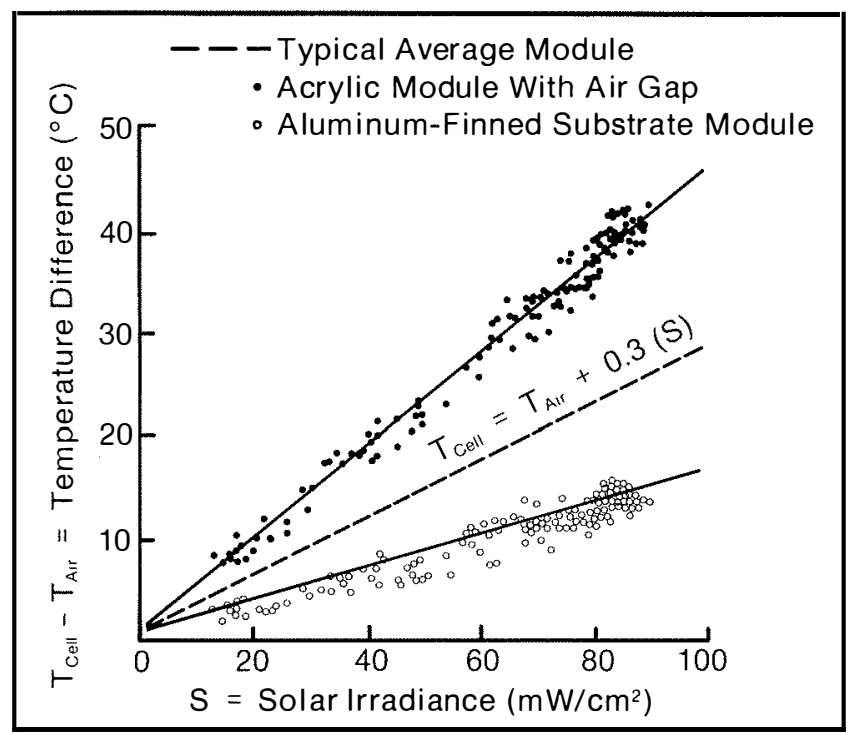

Figure 8. Cell temperature dependence on ambient air temperature and irradiance level; module temperature rise also depends on design and installation. The data shown are for an open back array with wind velocity of $1 \mathrm{~m} / \mathrm{s}$.

PV array performance can be expected to deteriorate somewhat over time. Losses are caused by module interconnection failures or a declining conversion efficiency. Decreased levels of performance (Figure 9) can result from less sunlight penetrating the cover of the PV module or deterioration of the cells. Dimin-

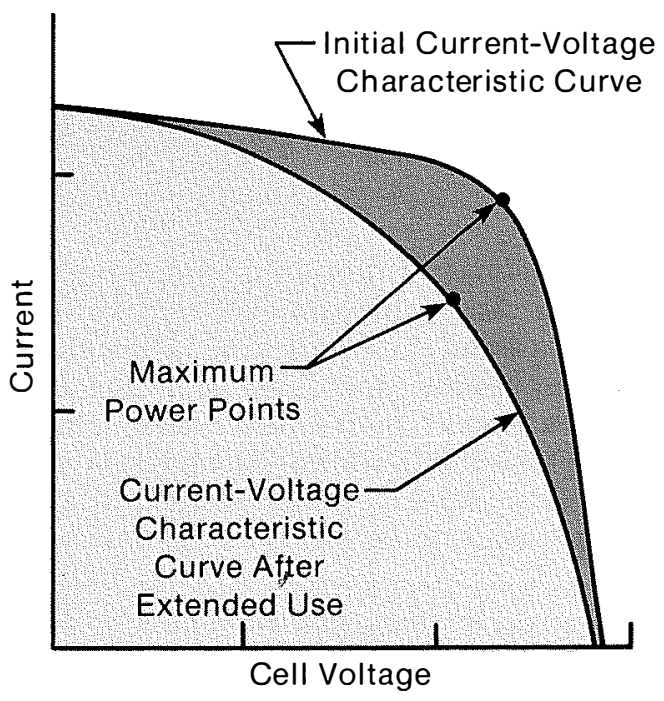

Figure 9. Cell performance can degrade. After about 10,000 hours of elevated temperature stress (about $55^{\circ} \mathrm{C}$ ), the cell tested showed as much as a $30 \%$ diminished output. Effect is most pronounced in "use" region of performance curve; open cell (maximum) voltage and short-circuit (maximum) current are minimally effected.

ished PV array performance is generally caused by deterioration of the module (a 10\%-30\% degradation may occur after 20 years). ${ }^{5}$ For example, degradation might occur when electrical contacts within the PV module or array fail after repeated stress from cycling thermal loads or repeated flexing under wind loads.

Conditioning PV Electricity. Banking excess PV electricity with the utility for withdrawal when it is needed mandates conversion of dc to ac electricity. This requires a key piece of equipment: the inverter (Figure 10). The dc to ac conversion must be made so

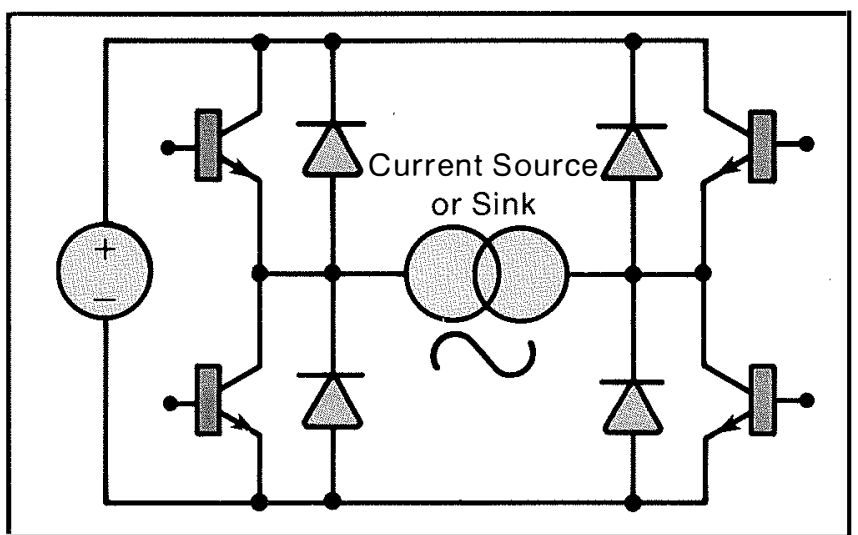

Figure 10. A basic inverter circuit contains 4 electronic switches, either silicon-controlled rectifiers, thyristors, or transistors (as shown). This circuit allows dc electricity to flow in one direction, and then in another.

5If a particular number of cells form a block, deterioration will depend on the number of blocks that are isolated from each other should a cell within a block fail. It should be $30 \%$ or less for a series of 25 or more blocks. 
that effects to the grid are acceptable to the utility. When PV electricity is sold to the utility additional equipment needs may include power meters at the residence, safety switches, and isolation transformers (often part of the inverter).

Inverters. The primary function of the inverter is to convert dc to ac. An equally important function is to insert electricity from the conditioned PV source into the utility grid with only small amounts of harmonic injection and a power factor and waveform phase difference (see "Fundamentals of Electricity") acceptable to the utility. The inverter should also provide good response to changing loads.

The simplest inverters reverse the polarity of output from the PV array 120 times per second to produce a square waveform that is inherently loaded with harmonics. More complex inverters shape the ac waveform to one resembling that from a utility, which in the United States is usually a $60-\mathrm{Hz}$ sine wave. With modern electronic digital control it is possible to shape the signal, adjust voltage output, and shift the phase angle between the utility's voltage and the inverter's current signals to satisfy utility requirements.

Inverter polarity can be internally (self-) commutated or externally (utility line-) commutated. The utility line-commutated inverter uses the grid signal to synchronize the inverter and grid power signals; the self-commutated inverter uses intrinsic electronics, an oscillator and circuits that lock-step the signal from the inverter with the utility line signal.

\section{Bibliography}

Basic Photovoltaic Principles and Methods. February 1982. SERI/SP-290-1448. Golden, CO: Solar Energy Research Institute; 69 pp.

Gonzalez, C. C.; Hill, G. M.; Ross, R. G., Jr. 1982. "Photovoltaic Array-Power Conditioner Interface Requirements." The Renewable Challenge: 1982 Annual Meeting of the American Solar Energy Society; Houston, TX; 1-4 June 1982. Edited by B. H. Glenn and G. E. Franta. Newark, DE: AS/ISES Publishing Office; pp. 909-914.

Gupta, Y. P. October 1981. Design Handbook for Photovoltaic Systems. SAND80-7147/I. Albuquerque, NM: Sandia National Laboratory.

Photovoltaic Systems Definition and Development Project. October 1980. SAND80-2374. Albuquerque, NM: Sandia National Laboratory; 414 pp.

Ross, R. G., Jr. 1982. "Reliability and Performance Experience with Flat-Plate Photovoltaic Modules." Proceedings of the Fourth E. C. Photovoltaic Solar Energy Conference; Stresa, Italy; 10-14 May 1982. Edited by W. H. Bloss and G. Grassi. Dordrecht, Holland: D. Reidel Publishing Company; pp. 169-178. 


\section{Chapter 2 \\ Incorporating Residential PV}

\section{Selecting a Suitable PV System}

Incorporation of PV into the design of a residential home requires consideration of appearance; proper integration of electrical components; the home's location; and how the home is built to use and conserve energy. Despite possible design and array differences, all residential PV systems should meet certain requirements. A system should produce electricity at a level that satisfies the homeowner. It should be reliable and virtually maintenance and hazard-free (Figure 11).

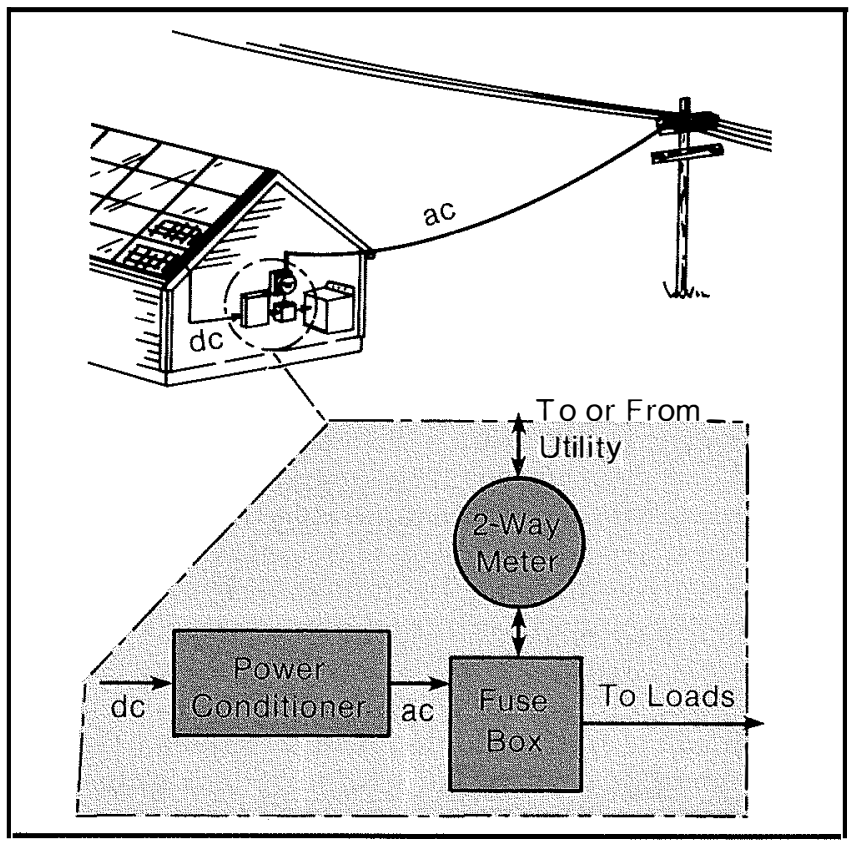

Figure 11. Generic utility-tied residential PV system.

The PV Array Mount. PV modules grouped into an array require the physical stability and positioning capabilities of a mounting system. An array pointed directly at the sun at all times produces maximum power (Figure 12). But, such systems must move with the sun and are impractical (for reasons of cost and complexity) for most residential PV applications. A typical residential PV array is roof mounted (in order not to use up yard space), faced permanently south, and elevated at a fixed angle from the horizon to within $\pm 10^{\circ}(\pi / 20$ radians $)$, complementing the latitude at which the residence is located. The position of the array is usually set to favor the time of year of maximum use of electricity. If sunlight-produced PV electricity is needed to power cooling equipment during hot summer months, then a low-tilt angle is desirable. If greater benefit can be obtained during the winter, the tilt angle should be at the steepest setting of the recommended range.

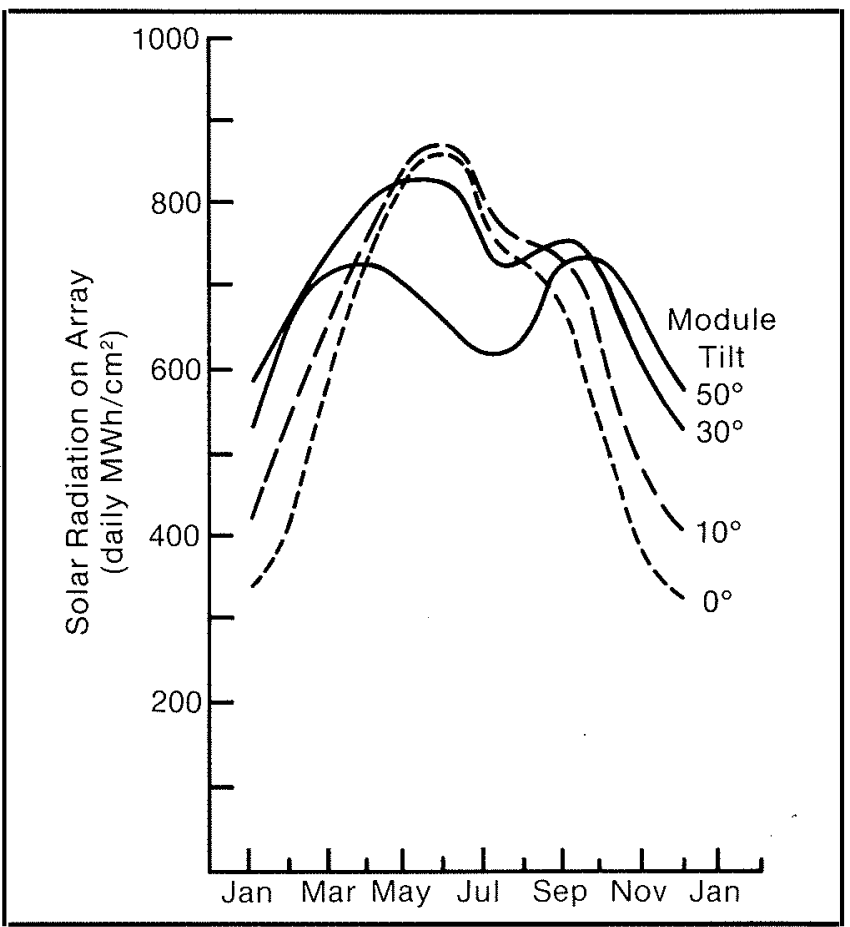

Figure 12. Performance of an array varies with tilt and season. Shown are relative responses of similar arrays located in the Southwest and set up at various fixed tilt angles.

A prime consideration with PV roof arrays is roof loading. A typical PV module $\left(1 \mathrm{~m}^{2}\right)$ will weigh $15 \mathrm{~kg}$ to $45 \mathrm{~kg}$. This load, in addition to other conventional roof equipment, must be supported by the roof. The mounting system used for the PV array can influence the costs of installation and maintenance. Retrofitting a house for PV may prove inordinately expensive if additional roof support must be provided. For these and other reasons, not all mounts are acceptable for all installations.

There are three basic PV array installation methods: integral, direct, and standoff (Figure 13). There is also a rack mount (a modification of the standoff design), different because the support does not parallel the roof. 

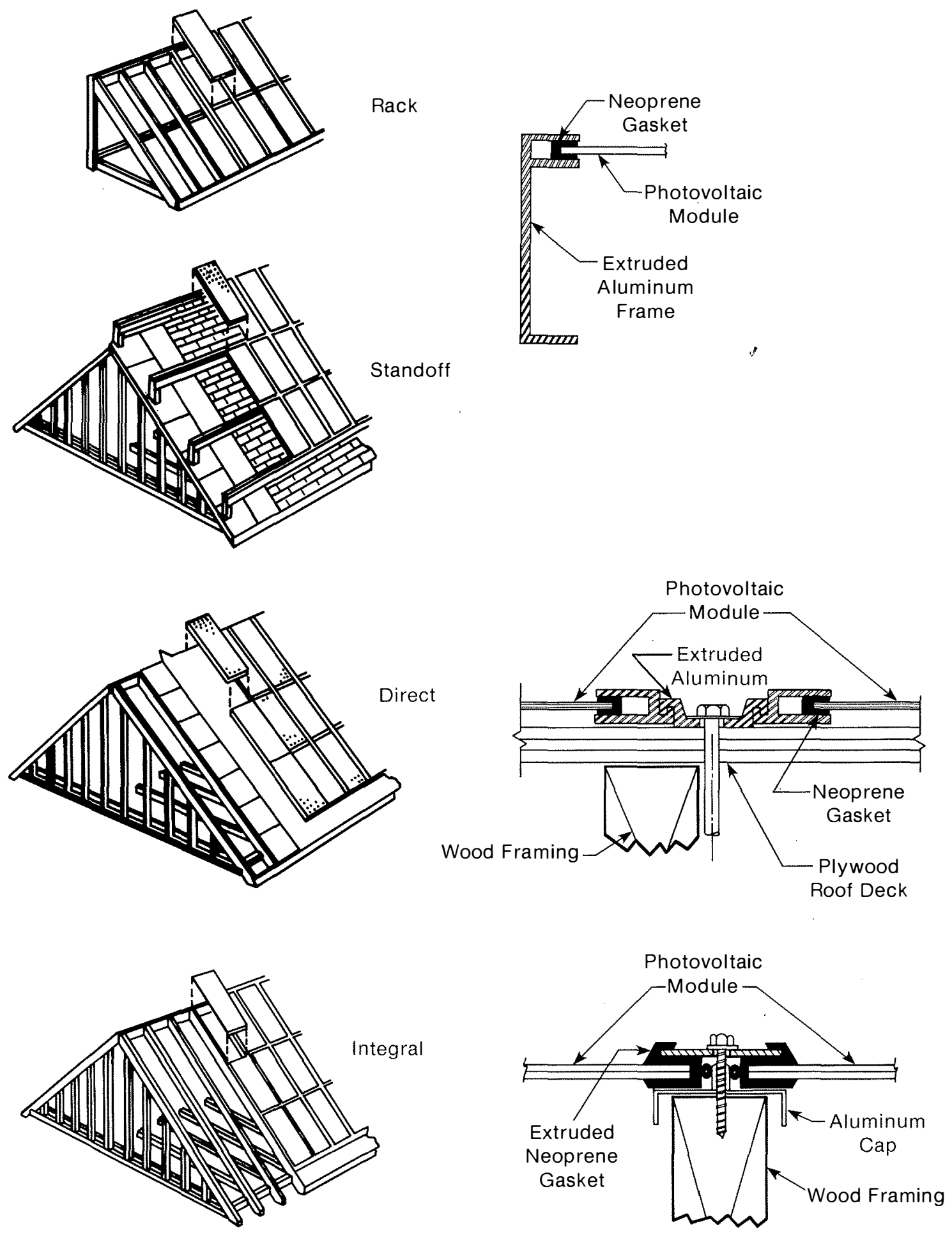

Figure 13. PV module mounting techniques.

The integral mount is used almost exclusively with new construction; the standoff mount for retrofitting. Although a house originally designed to include PV produces the best result, retrofitting of existing homes is not precluded. However, retrofitting usually involves redoing work previously done, extra time at a site by construction workers, and is less likely to be as low cost as installing a PV system at 
the time of the home's construction. Other potential pitfalls of retrofitting include adjustments for nonsouth-facing roofs, sunlight blockage by nearby buildings, lack of space for electrical conditioners, and lack of sufficient support structure or roof area.

A direct mount provides a more secure weather seal than the standoff mount. However, it tends to operate at higher temperatures because heat is released by convection and radiation from the top surface of the array (unless provision is made to add conduction cooling).

The standoff mount may cost the most to install initially since the roof and PV array are separate and independent. The aesthetics of the standoff mount may also be objectionable and the design subjects the roof to stress points. However, the long-term integrity possible with this type of mount may yield the lowest overall installation costs.

A typical rack-mounted installation on a flat roof provides full access to the front, rear, and sides of the PV array for module removal and maintenance and for reaching the module's electrical junctions. Circulation of air at both front and rear array surfaces helps maintain moderate operating temperatures. It requires considerable framing and hardware, however, and leaves spacebet ween the array and the roof where debris and snow may collect. The rack mount is primarily of interest in areas such as the American Southwest, where flat-roof home construction is common, and requires a PV array tilt of $25^{\circ}$ to $30^{\circ}$ (about $\pi / 6$ radians).

An aesthetically acceptable roof-mounted PV array depends on tilt, shape, size, color, texture, pattern, its concordance with the total roof design, and the subjective viewpoint of the observer. Square- or rectangular-shaped solar cells give a uniform appearance when densely packed in a PV module. Antireflective module coatings can be tailored so that the color of the array harmonizes with the rest of the roof. In addition, aluminum frames for modules can be anodized to a dark color resembling that of the PV cells, softening disharmonies between the appearance of the roof and the array.

Consideration must be given to the maintenance of the mounted array in addition to its operational integrity, aesthetics, weight and cost. Modules may be either glass- or plastic-encapsulated. Glasscovered panels rank high for their ability to remain clean and clear without undue care. Some plastic encapsulants do almost or just as well in their ability to wash free of dirt with the assistance of heavy rains, but they tend to cloud faster than glass. Plastics are lighter than glass, making it easier to install (or replace) the panels. They are also less likely to fracture under hail or stress; but, they are flammable. Selection of plastic or glass for protection of the array is also dependent on location of the residence. Where soiling is not a problem, all encapsulants will remain relatively free from dirt and occasional wash- ings will keep the arrays clean. Where soiling is a problem, and rains are not heavy, the choice of plastics may be limited. Certain airborn soiling agents can only be removed with detergents, which may cause plastics to degrade.

System Size. Personal as well as economic factors influence PV system size and are part of the buyer's decision process. Size, however, is a secondary issue that becomes a consideration only after the decision to buy has been made.

Surveys have shown that candidates for residential $\mathrm{PV}$ see the system as economically viable dependent on the local cost of electricity, regional environment (climate, sun intensity and availability, etc.), and style of living.

One type of potential buyer may view residential PV as a desirable "extra," competing with such amenities as a tennis court or swimming pool. Here the motivation is prestige and perhaps security from utility outages. Other residential PV buyers may be mindful of PV's security, but actual purchase will depend on perceived economic gain, where energy or cost savings are equal to or less than those of a nonPV residence. [A southwest U.S. home with high energy demands (for cooling) during PVs working hours could produce noticeable energy savings.]

The size of the selected PV system will depend on the buyer's intended energy uses. A customer who wants to sell more electricity than is purchased will tend to favor a large system, possibly incorporating modules into the south-facing wall as well as on the roof. High-utility buyback rates favor the rationale of this strategy. However, the aesthetic appearance of a roof (or wall and roof) completely covered by a PV array may be questionable. A customer's preference may be to achieve a zero net load so that the on-site electricity generated each day (on average) equals that used. Another customer preference could be to size the PV array to meet the average actual daytime load with a small (2-4 kWp) system. Underlying this concept is the idea that a large portion of the PVgenerated power can be used immediately, on site. ${ }^{7}$

PV electricity's application and the components needed for a given residence influence system size. Installation area limits the size of typical residential systems to 7 kilowatts peak ( $\mathrm{kWp}$ ). Systems must be rated practically (at least $2 \mathrm{~kW}$ ) because of the variation in the amount of electricity that can be produced annually. Output varies with climatological area from 1000 to 2000 kilowatt hours (kWh) per rated kilowatt peak, with $1500 \mathrm{kWh}$ being typical.

\footnotetext{
${ }^{6}$ The important factor with regard to buyer savings should be megawatt-hours per year of alternating current produced per dollar invested.

${ }^{7}$ This case is not particularly relevant to the systems covered here. Many homes will have difficulty in sustaining an appreciable steady base load, a prerequisite for fulfilling the intent of the concept. However, the Future 1 house in Georgia is said to have used as much as $80 \%$ of the PV electricity produced.
} 
Size will also depend on where the house is located. Location can affect power or energy output per unit area of array. For example, a solar array placed in Arizona, on average, will produce more current than the same array in New England (Figure 7). On the other hand, the voltage from the same array in Maine may be $20 \%-25 \%$ greater than that in Arizona since it will generally operate at a cooler temperature; a PV collector's efficiency generally increases as ambient temperature decreases.

Cost. A primary consideration in selecting a PV system, irrespective of sizing factors, is cost. The array is the most expensive component because of the high price of PV cells. Although the overall cost of a residential PV system in 1982 ran from $\$ 15 / W^{8}$ installed, certain steps may be taken to keep costs lower (perhaps below $\$ 10 / \mathrm{Wp}$ ). These include choosing hardware that keeps site application work or engineering rework to a minimum; using the most standard designs and components; buying only the equipment that is needed (avoiding high cost items) to meet utility tie-in requirements; and, selecting designs with low installation costs (e.g., those that are modular).

In addition, system lifetime costs can be kept low by selecting components with the highest warranted power output and efficiencies over the longest performance period; obtaining components that provide adequate reliability and minimal maintenance; and selecting components (particularly arrays) that operate at low temperatures for longer life performance. ${ }^{9}$

\section{Interconnection}

The technical factors involved in grid-tied residential PV involve the switching in and out of generator capacity, the harmonic content and PF of electricity fed into the utility grid, equipment for achieving goals cost-effectively, and a foolproof mechanism for disengaging the PV system from a failed grid.

Residential PV harmonic voltages introduced by the inverter's chopping or commutation can raise utility voltage harmonics to unacceptable levels. Utility grids typically contain low harmonics levels; in the range of $0.5 \%$ to $2 \%$ total harmonic distortion. The Electric Power Research Institute (EPRI), the Institute of Electrical and Electronic Engineers (IEEE), and others are developing standards for allowable limits on harmonics fed into the utilities for buyback or cogeneration systems.

Inverter-induced PF losses can be tolerated by a utility for only a handful of residential PV installations

\footnotetext{
$8 \mathrm{Wp}=$ watts peak, or the power obtainable at $1000 \mathrm{~W} / \mathrm{m}^{2}$ of sunlight at the cell's optimum operating temperature.

${ }^{9} \mathrm{~A} 10^{\circ} \mathrm{C}$ temperature reduction reportedly can increase the life of an array by a factor of two.
}

without compensation. When undertaking compensation, utilities increase their costs for PF-correcting line capacitors and costs associated with oversizing of distribution-line components. Utilities also face possible system resonances caused by PF-correction hardware, and excessive line voltages at certain PFs.

EPRI, IEEE, and others have identified additional areas requiring standardization for a PV-grid interface. They include the following:

Insolation. Direct current from the PV array must be isolated from the transformer or other utility load should there be a failure (e.g., a problem internal to the inverter).

Distribution Transformers. Transformers on the utility line must be sized to contend with possible PV output peaks.

Utility Disconnect. System and personal safety demand redundant methods for disconnecting the PV source from the utility grid in case of power outages (Figure 14), over/underfrequency variations, and over/undervoltage variations. Procedural uncertainties associated with these items include methods of

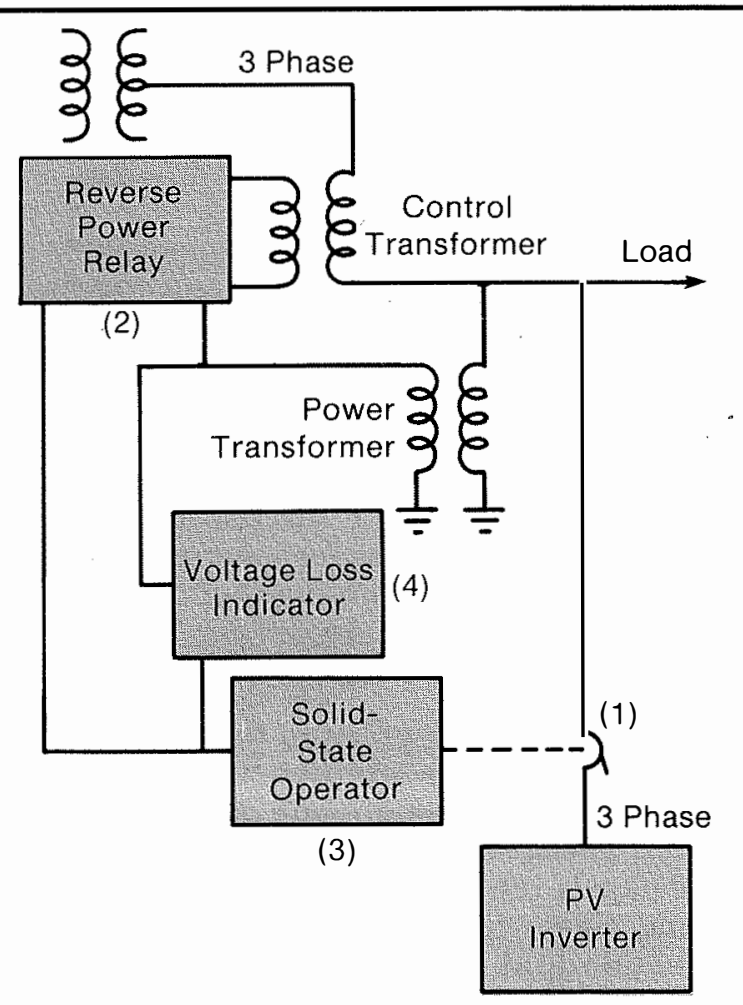

(1) Five-cycle breaker to interrupt PV circuit.

(2) Reverse power relay, trips for reverse power on any one phase.

(3) Solid state control for breaker 1

(4) Trip signal if voltage falls below specified limit.

Figure 14. Reverse power sensing circuit provides positive shutdown during utility outage. 
disconnecting the PV system, monitoring techniques relative to the power-conditioning subsystem; limits on voltage and frequency variation, time delay, and response time of the disconnection scheme; and a definiton of what constitutes an outage. Several IEEE technical committees, among others, are working on these problems.

Grounding. PV system grounding criteria need defining. This issue is being addressed by a panel of the National Electrical Code.

Interface with Service Panel. For safety, a suitably located point must be standardized for the PV system to feed ac power into the service panel on the utility side of the main breaker.

Other problems involve operating responsibilities and standards such as maintenance responsibility for the various components of PV system equipment.

\section{PV On-Site Use}

The price that the utility pays for electricity from the homeowner may be less than that charged by the utility to the homeowner. The homeowner therefore may be better off to use the PV electricity directly than to sell it all to the utility and subsequently repurchase it. Depending on the utility, the homeowner tied to the grid may have the option of applying PV electricity for immediate use. As a further option he may elect to use the PV electricity without converting to ac. However, few would use the last option because it complicates the home's wiring system and the purchasing of electrical appliances.

In instances of on-site use of PV electricity, additional considerations may apply. Since applicances rarely are in continuous use, the electrical load of a residence fluctuates, causing the PV power being sold to the utility to fluctuate. A steady-power consuming appliance will cause less power to flow to the utility than an appliance (or series of appliances) that cycles on and off. In the sense that power is most effectively used as it is produced by a PV system, that system is best matched with a load that is constant, rather than intermittent. Thus, appliances that operate intermittently, especially those that need a lot of power, are not well matched to photovoltaic systems designed for on-site use of PV power. Refrigerators and freezers that operate at low wattage with long "on" cycles are good matches; clothes dryers and ovens, with heating elements that frequently cycle on and off, are poor.

Substituting a heat-pump water heater for a conventional, electrical-resistance heater improves the match between heat source and an average-size, residential PV power source $(4000 \mathrm{~W})$ because the power used $(2250 \mathrm{~W})$ is more wihtin the capability of a PV system than that of a conventional electrical heater $(4500 \mathrm{~W})$.
Bridging the Production/Use Mismatch. Peak U.S. residential electric demands generally occur between 7 a.m. to 8 a.m., and in the evening (Figure 15). For PV residences, where solar-generated electricity peaks at midday, there may be strong incentive to reduce evening demand by shifting some appliance use to an earlier period, either automatically or manually.

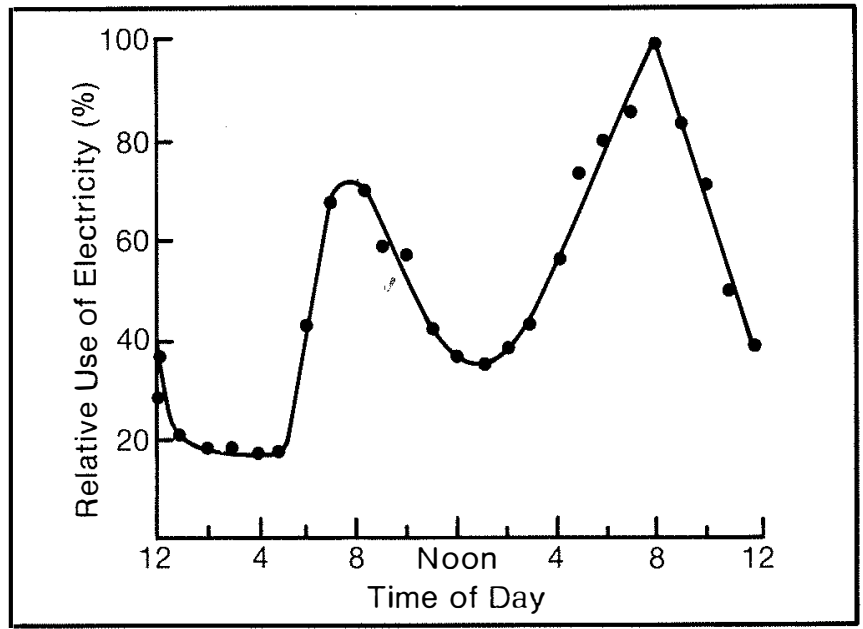

Figure 15. The hour-by-hour use of electricity in a typical home shows two peaks. Curve is a composite from several Northeast homes during autumn weather.

On Site Storage. In addition to using PV electricity as it is produced, the homeowner may use storage, such as batteries. Some designers are of the opinion that on-site storage is of little practical value since it introduces additional equipment that cannot pay for itself and additional maintenance problems. They favor directing electricity in to the utility grid. Others believe that some on-site storage can benefit the utility-tied residential PV concept. One reason is that a storage system can be used as a ballast allowing simplification of the power conditioning equipment.

Any decision regarding PV's direct use, sell back to the utility, storage, or a combination of these methods depends on the specific type of residence and its location. Although many systems may ultimately prove feasible for storing PV-produced electricity at a residence (flywheels ${ }^{10}$, fuel cells, etc.) only batteries are now viable.

The battery storage system is commercially available, has no-moving parts and, is noiseless. It allows for repairs to part of the system without total storage

\footnotetext{
${ }^{10}$ Compared with the test battery, some researchers believe the flywheel promises to return as much, or more of the energy fed into it. Although batteries have better energy-storage capabilities, their actual performance is diminished by non-optimal discharges and parasitic losses to conditioning equipment. Flywheels have a longer life expectancy (20 years versus 5 years), consume less space ( $\mathrm{m}^{3}$ versus $4 \mathrm{~m}^{3}$ for $4 \mathrm{kWh}$ ), pose fewer hazards to those occupying a residence, and do not need a device to convert dc to ac.
} 
shutdown and additional storage capacity may be added in increments. However, compared with the grid inter-tie option, storing electric energy from - residential PV systems on-site is costly ${ }^{11}$ and requires a secured-access area. Also, the battery system normally requires additional voltage-regulating equipment.

\section{Bibliography}

Brench, B. L. 1981. "Operational Experience in LeadAcid Batteries for Photovoltaic Systems." Proceedings of the Fifteenth IEEE Photovoltaics Specialists' Confernce; Kissimmee, FL; 12-15 May 1981. 81CH16444. New York: IEEE Publishing Service; pp. 642-647.

Forman, S. E.; Klein, B. N. January 1982. Safety Inspection Guidelines for Photovoltaic Residences. DOE/ET/20279-195. Lexington, MA: MIT Lincoln Laboratory; $38 \mathrm{pp}$.

Hannifan, M., et al. "Design Guidelines for Residential Photovoltaic Experiments." SERI correspondence, September 1981.
Interim Standard for Safety: Flat-Plate Photovoltaic Modules and Panels, Vol. I: Construction Requirements. February 1981. JPL 5101-164. Pasadena, CA: Jet Propulsion Laboratory; 20 pp.

Kern, E. C., Jr. 1980. Residential Photovoltaic Systems. DOE/ET/20279-99. Lexington, MA: Massachusetts Institute of Technology; 4 pp.

Marketing and Market Acceptance Data from the Residential Solar Demonstration Program: Vol. I. 1981. HUD002073. Prepared by the Realestate Research Corporation, Chicago, IL; 203 pp.

National Electrical Code 1984. August 1983. "Article 690 - Solar Photovoltaic Systems." Quincy, MA: National Fire Protection"Association; pp. 613-619.

Safety and Liability Considerations for Photovoltaic Modules/Panels. January 1981. DOE/JPL-95584681/1. Pasadena, CA: Jet Propulsion Laboratory; 52 pp.

Sillman, S. 1982. The Analysis of On-Site Use and Sell back in Residential Photovoltaic Systems. SERI/ TR-254-1444. Golden, CO: Solar Energy Research Institute; 69 pp.

\footnotetext{
11 The disparity between the cost for on-site and grid-inter-tied storage is expected to lessen as smaller, lighter-weight, more efficient, longer-lived, and inexpensively produced equipment becomes available.
} 


\section{Chapter 3 \\ Factors Influencing Implementation}

Efforts are being made to overcome the potential obstacles discussed in the previous chapters. Among them is a program that was undertaken, beginning in late 1979 , to determine the variables affecting residential PV designs in various regions of the United States. The Department of Energy established regional Residential Experimental Stations (RES) in the northeast, southwest, and southeast (see Appendix). The RES program exists to research, test, evaluate, and provide technical information on residential PV requirements for the particular regions.

The test facilities, because they are based on prevailing technology, produced valuable qualitative information, serving to confirm or disprove concepts as well as suggest avenues for improvements. Results from the test sites so far have shown how, and possibly why, array performance might deviate from controlled-condition testing at fixed, preselected points. For example, as interpreted by RES researchers, the data have shown that:

- An increasing angle of incidence or apparent color or intensity change of the sun effected a smaller performance change with some arrays than others.

- The mounting configuration appears to be less important than the way in which array panels are constructed in establishing operating temperatures of the PV system. The specific attributable factors such as encapsulant, substrate design, etc., are still under investigation.

- Typically, $60 \%-80 \%$ of the PV-generated RES electricity is sold to the utility because of source/load mismatch (Figure 16). This occurs even where there is an attempt to sell only excess electricity to the utility and use all possible PV electricity on site.

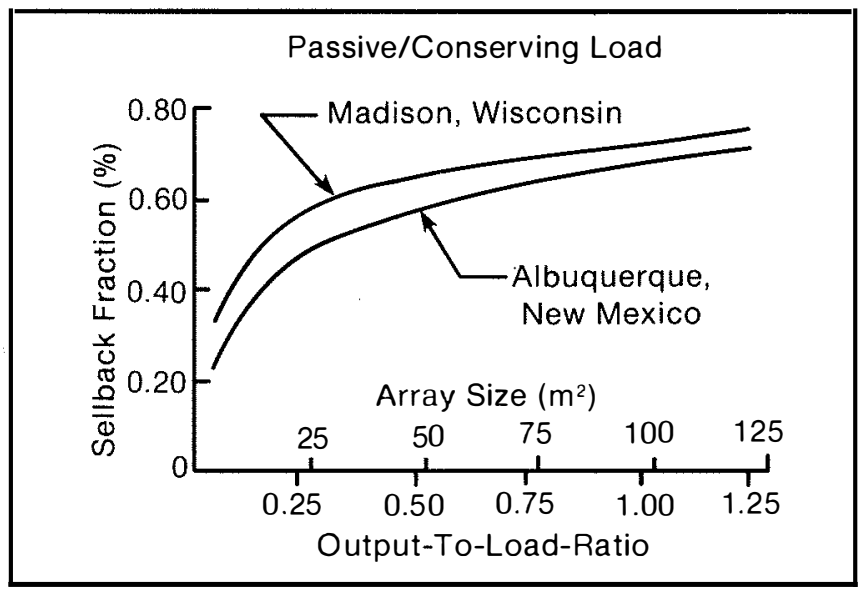

Figure 16. Theoretical calculations of residential PV power available for buyback by the utility.
- Constant-voltage operation is only $2 \%$ less efficient than maximum power-tracking operation.

RES results are also expected to clarify some nonengineering issues, including the economic circumstances justifying PV's application to homes. However, the RES experiments do not cover socioeconomic factors relating to the widespread adoption of PV residential-utility grid inter-ties. These considerations include environmental factors, solar-access rights, standardization, insurance, buy-back rates by utilities, and system longevity.

\section{Legal and Environmental Factors}

As noted earlier, high cost is a major consideration when implementing residential PV, although some small amelioration is available from federal and some state governments. The federal government allows the homeowner living in-residence to credit $40 \%$ of the cost of a solar installation - to a maximum of $\$ 4000$ - against taxes due.12 About half the states of the United States currently provide separate tax rebates. Generally, the maximum state tax credit, where one is available, is $\$ 1000$.

\section{Solar Access}

Observations have shown that during "prime-time solar" (10 a.m. to 3 p.m.), homes within most communities, regardless of a community's age, have good access to the sun. The certainty that such access will continue is obviously important; without it the costeffectiveness of the PV system is dubious. Shadowing will, of course, cut the production of electricity. Worse, partial shadowing, whereby a portion of the module is in the sun and the remainder is shaded, can create hot areas within the inactive cell regions that are not conducting and pose a potential fire hazard. A few states (e.g., New Mexico) have established solarrights statutes. The broader adoption of such ordinances seems imminent and scattered progress is being made in establishing local laws (e.g., Los Angeles, California and Boulder, Colorado) to assure a homeowner of uninterrupted access by the PV array to the sun. In the absence of local or state laws, it is possible to create private agreements binding property purchasers and their successors to abide by construction codes (e.g., easements) that proscribe obstruction of the sun (Figure 17).

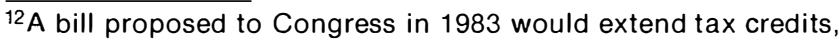
scheduled to expire in 1985, to 1990.
} 


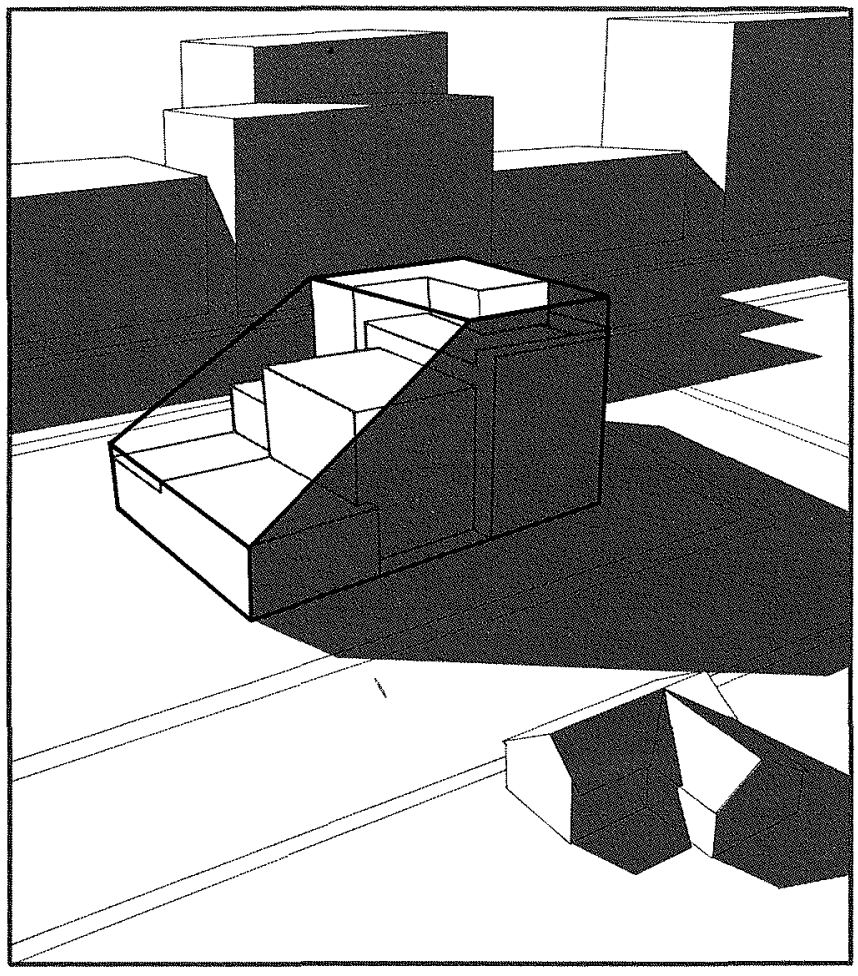

Figure 17. Demonstration of envelopefor avoiding the blockage of sunlight. Buildings may be properly designed to avoid casting shadows on others.

\section{Building Codes}

No codes exist for building homes with residential PV systems. This presents possible problems for a PV home builder who must obtain construction approvals. Building inspectors can be reluctant to approve a PV residence without having guidelines. Certain institutions, such as the Underwriters Laboratory (UL), are working to develop residential PV standards; but, in their absence it is important, prior to construction, to establish ground rules with the building inspector about what will or will not be acceptable.

\section{Insurance}

Insurance companies do not differentiate between solar thermally heated and conventionally heated homes. Rates and coverage are comparable. However, the criteria for solar PV homes is only now being established.

Primarily, insurance companies are concerned that systems are properly integrated, constructed, and installed. In this regard, retrofit PV is less likely to merit good insurance ratings than a PV system designed as an integral part of a residence. There are insurance underwriters who feel that future insurance rates for $\mathrm{PV}$ residences will be the same as those granted for conventional homes; they tend to regard properly installed solar systems as no more than a regular risk. A substantial number of underwriters, however, are unwilling to speculate on future rates because of a lack of data. Even now, in some areas of the country, PV homeowners are requested by the utility to carry liability insurance covering possible damage to its grid or to other utility customers.

The National Fire Protection Association has established committees to address all electrical safety concerns associated with residential PV system installation. These efforts are aimed at identifying existing national electrical codes and establishing new ones specifically relating to residential PV installations for the 1984 edition of the National Electrical Code (NEC) handbook.

\section{Utility Buyback of Residential PV Electricity}

Contract details for purchasing electricity from residences remains to be formulated by most utilities. The Public Utility Regulatory Policies Act (PURPA) of 1978 set general guidelines. The law obligates utilities to purchase electricity generated at residential, commercial, and industrial sites if the installations haveless than a specified generating capacity. According to government regulations, the purchase price is to equal the utilties' avoided costs.

\section{PV System Longevity}

In theory, PV systems should be among the most reliable of electrical generators since their function does not depend on parts that move and are subject to mechanical wear. Many custom-built, PV systems with redundant components, such as those for the space program, have been operating for more than 20 years. On the other hand, test programs of residential systems have brought out failures of one or more system parts within the first years of operation, indicating possible design shortcomings in the PV panels and power-conditioning equipment. Some of the systems tested had extended downtime - a point of irritation. Some off-line time was attributable to repeated system failures; additional downtime was incurred waiting for repairs. Generally, overall reliability and maintenance has improved during the last few years.

\section{Bibliography}

Solar Envelope Zoning: Application to the City Planning Process. September 1982. SERI/SP-281-1651. Golden, CO: Solar Energy Research Institute; 120 pp. 
This monograph has been devoted to an elementary technical analysis of factors entering into the use of photovoltaics for residences that are tied to a utility grid. The concept underlying the widespread acceptance of residential PV is that all electricity produced by the PV system is sold to the utility, and the electrical needs of the home are supplied from the utility's lines. The reason for underscoring this approach is that, according to many experts in the residential PV area, a total two-way exchange is necessary to reach significant levels of enèrgy production from residential PV in the United States.

The prognosis regarding adoption of two-way, gridtied residential PV depends heavily on the cost of installation. Experts differ in their assessments of what will induce consumers to accept utility-tied residential PV. Their predictions fall primarily in the cost range of $\$ 1$ to $\$ 3 / \mathrm{Wp}$ (1982 dollars). They agree that this range is achievable, but when it will be achieved remains problematic.

Whether the cost incentive will be at the high or low end of the $\$ 1$ to $\$ 3$ range, or in between, depends on the cost of conventionally produced electricity. The latter depends in good measure on the cost of such fuels as oil and gas. PV system prices should drop as they do for many technologies that encounter growing acceptance. Oil economists forecast that the price for fuels will continue to rise at a rate greater than that for inflation, despite temporary aberrations. These two cost changes could encourage acceptance of residential PV among homeowners during the coming years.

Speedy acceptance of $\mathrm{PV}$ for residential applications will also depend on how imaginative the homeowner, architect, and builder can be. Builders and architects may elect to forego all or part of their customary markup for the PV portion of the home. Several homeowners may choose to enter a corporate arrangement; profiting from tax writeoffs not available to individual homeowners, and thus shifting the $\$ 1$ to $\$ 3$ cost range, at which the system is expected to be cost effective without solar credits, to $\$ 2$ to $\$ 4.50$ (1982 dollars). Use of PV in large residential developments may also foster general acceptance since such implementation would have economy of scale (including factory-direct prices, smaller per-unit shipping costs, fixed-contract installation prices, etc.).

Another factor will bethe financing arrangements available to homeowners selecting PV. Partitioned loans with different terms for the home and the PV system - the latter at incentive, possibly subsidized, rates - could promote earlier acceptance.

Cost considerations aside, there are definite benefits to residential PV that aid its acceptance. From the homeowner's perspective, residential PV affords a certain independence from the utility. Also, based on experience with solar-heated homes, PV's inclusion in to the home's design can be expected to increase the ease of sale or resale and the selling price of the home.

From the utility's perspective, residential PV may postpone the need for new capital equipment as the area's population grows. Residential PV may actually reduce use of obsolete, high cost equipment previously needed for meeting peak demands and add, incrementally, to the utility's capacity to meet system demands, making utility management decisions about future needs less critical.

There are, of course, detractions (other than capital cost) from using PV in residences. For example, the homeowner who finances the system bears extra installment costs and increased maintenance needs. The utility, for its part, relinquishes some control of its supply.

Overall, expanding technological developments, lowering PV costs, and increasing the awareness of architect, builder, and consumer about the capabilities and ramifications of PV's use, are leading many experts to predict a successful future for PV systems in residences acting in a two-way energy exchange with utilities. 



\section{Appendix}

The testing approach undertaken by the contractors of the DOE-sponsored northeastern, southwestern, and southea stern station s has been simple and direct: Construct a diversity of systems - different PV arrays, power conditioners, and roof integration techniques for creating full-size residential PV systems - and then evaluate design and performance. These systems were to be representative of state-ofthe-art equipment. The purpose underlying this procedure was to develop, an insight into possible pitfalls in the installation, operation, and maintenance of the systems without necessarily making critical comparisons among them. The data were used to analyze the interaction of energy used and produced as it relates to environmental factors, focusing on requirements for the specific region. Another purpose of the regional projects was to establish realsituation relations between the PV component manufacturers, home builders, utilities, and other relevant organizations (i.e., code officials, insurance underwriters, and bankers).

In the northeast, system hardware development involved two phases. First, prototype systems were installed at a Residential Experimental Station (RES). The PV arrays for these prototypes were mounted onto the south-facing surface of a roof structure, set up in lean-to fashion several feet above the ground and sheltering a small storage space for the control and monitoring of equipment. Abundant instrumentation provided detailed engineering performance and reliability data - testing for weather effects, leaks, module degradation - and a working measure of the extent of utility cooperation. The PV arrays were tied to utility-interactive dc-to-ac powerconditioning equipment.

A second-phase of the project placed refined versions of some of the experimental prototype systems on houses built for testing in the community surrounding the experimental station. These systems were to assess an occupant's reactions to residential photovoltaic systems. Such lived-in residences were referred to as the Initial Systems Evaluation Experiment (ISEE) and were considered to be a meaningf ul element in the development program, providing engineers with effects relative to the ways in which a given family uses its home.
Northeast activities include five prototype systems and one ISEE. All are located in eastern Massachusetts; all use simple photovoltaic systems designed to exchange energy with an electric utility grid.

Another RES complex began operating in Las Cruces, New Mexico in 1981. Eight prototype systems, similar to the Northeast RESs are being evaluated for the effects of hot-arid operation.

The Southeast RES consists of PV installations on the roofs of three shell homes, each home being typical of the area. Work commenced in 1983. The work at the Southeast RES is similar to that at the other regional RESs - with some important differences. The effort is on a cost sharing basis, with state university and public and private utility involvement. There is greater utility interfacing with residential PV facilities in the selling and buyback of electricity. All test-house construction was done with regular contract labor (a s op posed to specially trained crews). Efforts at the Southeast RES specifically included testing of various passive cooling measures of the PV panels.

Residential photovoltaic projects have also been undertaken at Cape Canaveral, Florida; Phoenix, Arizona; Honolulu, Hawaii; and Arlington, Texas.

Each prototype system in Massachusetts, New Mexico, and Cape Canaveral is operated with equipment to mimic real loads. Simulated loads are used because the presence of an occupant in an experimental structure could complicate the gathering of engineering data. Several lived-in homes, typical of energyconservation and located near each Northeast RES, were instrumented to provide data for simulating instantaneous electric-power loads at the experimental units. Instruments at the RESs are used to monitor system response to the loads; data outputs are connected to central data-logging equipment. Objectives are to determine the effects of the weather on energy demand (e.g., space-conditioning loads) and the indirect effects caused by weather-related changes in energy-use patterns (e.g., increased lighting and appliance use during bad weather).

The RES tests do not account for the possible shifting of discretionary loads by occupants in order to take greater advantage of on-site generated electricity. 